\title{
Wrath in \\ Diane Wakoski's Poetry
}

\section{Luis Gustavo Álvarez Martínez}

Universidad Nacional, Costa Rica

The act of writing poetry is not an easy task, but it becomes even more difficult when the poet is a woman who has to struggle with her writing under the oppression of a patriarchal society. This situation has affected the writing of various contemporary American poets. An aspect that captures my attention is that in their poetry many female poets refer to men with a great deal of wrath and anger.

This is the case of Diane Wakoski whose poetry I will analyze in this essay from the perspective of her attitude toward certain male figures who have caused this anger that is expressed in her literary works. By no means is this article an attack on Wakoski's poetry or that of any other female poet. On the contrary, its purpose is to clarify and contribute to the comprehension of how any writer's literary work is affected by the experiences and events at a particular time in history.

Diane Wakoski was born in the United States in Whittier, California, on August 3, 1937, and attended the University of California at Berkeley where she received her BA in 1960. Her first book of poems appeared in 1962; however, it was not until 1966, when she won a Robert Frost Fellowship and published Discrepancies and Apparitions, thatany significant amount of her work began to circulate more widely. Wakoski has taught at a variety of institutions and has been, since 1976, writer-in-residence at Michigan State University. ${ }^{1}$

1. Richard Ellmann and Robert O'Clair, eds., Norton Anthology of Modern Poetry, 2nd ed. (New York: Norton, 1988) 1486. 
In her article, "When We Dead Awaken: Writing as Re-vision," poet Adrienne Rich points out the theme of male oppression in Wakoski's poetry: "it strikes me that in Wakoski's work man appears as, if not a dream, a fascination and a terror; and that the source of the fascination and the terror is, simply, man's power to dominate, tyrannize, choose, or reject the woman." ${ }^{2}$ To demonstrate this aspect of anger and oppression in her poetry I will comment first on her poem "The Father of My Country."3

In this poem Wakoski depicts her difficult childhood and the lack of a relationship with her father. It is obvious that she wants to have a father. To a certain extent her poem evokes sympathy because in those formative years it is generally accepted that there is a need for a father-child relationship to achieve a sense of security. There is no doubt that this first, and certainly most important male figure in her life, was an irresponsible man, and this resulted in her being an insecure child. As an example of this she states, "My father / made me what I am / a lonely woman / without a purpose, just as I was / a lonely child / without any father." ${ }^{4}$ In this poem, she takes the figure of George Washington as her hero as well as her loneliness to substitute for her father. Wakoski says, "George you have become my father / I need your love / I want to call you Father, my Father." 5 So, figuratively speaking, if it were not for George Washington she would not have had a father figure.

Feminist critic Alicia Ostriker in herbook, Stealing the Language, addresses Wakoski's poem, "The Father of My Country," saying that "it reconstructs the child Wakoski's desperate love and need of the absent, indifferent father who has created her identity and betrayed her." ${ }^{6}$ This poem shows very powerful and angry images in which

2. $\quad$ Adrienne Rich, "When We Dead Awaken: Writing as Re-vision," Norton Anthology of Literature by Women, eds. Sandra M. Gilbert and Susan Gubar (New York: Norton, 1985) 2046.

3. Ellmann, 1487.

4. Ellmann, 1490.

5. Ellmann, 1490.

6. Alicia Ostriker, Stealing the Language: The Emergence of Women's Poetry in America (Boston: Massachusetts, 1986) 156. 
Wakoski desperately wants the father figure that she could not have during her childhood. Now this causes her problems with other male figures. For example, in line 98 she says, "father who makes me know all men will leave me if I love them."7

The relationship between herself and the men in her life is an antagonistic one in which she cannot posses them, so there is hatred toward them and also an emotional submission. She shifts from one father or love figure to another. For instance, in her poetry we find male figures such as George Washington, her father, Beethoven, truck drivers, Bach, lovers, Ben Franklin, and the hitchhikers. Even more, she also takes on the masculine imagery of military men, bikes and mustaches. As Wakoski interviews assert: "The act of writing is an act of completion. If you get what you want, you do not write about it. You write about what you don't get." 8 Thus, the anger of her poetry is a desire for what she cannot obtain in life.

Reading her poem "Thanking My Mother for Piano Lesson" after having read "The Father of My Country," it is possible to understand why Wakoski feels betrayed by her father and as a result the anger becomes a distinctive feature of her poetry. "Thanking My Mother for Piano Lesson" is a poem in which she expresses her thankfulness toward the female figure-her mother. In it she says, "I want to thank / my mother for working and always paying for / my piano lesson."9 Through this comparison, we can see the love of a mother supporting her child. Unlike her father, she is always there to protect and help her insecure child. This poem portrays a woman who is abandoned by her man and must play the roles of both mother and father.

At the same time, it also presents the lack of a father figure and the damage this can produce in children during their development. Wakoski still misses her father and wants to be identified with a male

\footnotetext{
7. $\quad$ Ellmann, 1489.

8. Ostriker, 81.

9. Ellmann, 1491.
} 
figure. She says, "wanting only to be touched by a man who loved me / who would be there every night / to put his large strong hand over my shoulder." ${ }^{10}$ Her life has not been easy and the poetry she writes is a way to relieve her wrath and frustration caused by certain male figures. As she says in an interview with Claire Healey, "I grew up feeling pain and ugliness, didn't dwell as much on myself as on the social situation of being poor and living in an ugly world."11

In the poem "Thanking My Mother for Piano Lesson," the function of the piano as a metaphor for her confrontation with her past is an important aspect to analyze. The piano represents an instrument that she used to relieve all her anger and pain. It might well be a substitute for her father through which she plays out her insecurities. It is through the piano lessons that she overcomes the pain and fear caused by the absence of her father. She says, "But I played my way / on the old upright piano / obtained for $\$ 10$, / played my way through fear, / through ugliness." 12 It is clear that her piano lessons reflect another phase of her dark childhood, the search for love and beauty. Wakoski herself has said, "Another aspect about my childhood is playing the piano, which for me was pounding out the ugliness around me, making the sounds which were beautiful, to drown out everything else." 13

Another interesting poem that shows Wakoski's wrath and the reasons for her anger is "No More Soft Talk." In this poem she wants to be hard as a rock in order to avoid pain or getting hurt. Women have always been related to softness and have been considered the weaker sex, while men are supposed to be strong and never show their feelings. She explains very well why women do actions they do not want to do just because they live under the influence of this phallocentric society. She says, "I am trying to think how a woman /

\footnotetext{
10. Ellmann, 1492.

11. Claire Healey, "An Interview with Diane Wakoski," Contemporary Literature 18 (1977) 6.

12. Ellmann, 1492.

13. Healey, 18.
} 
can be a rock, / when all she wants is to be soft / to melt to the lines / her man draws for her." ${ }^{14}$ Moreover, in this poem Wakoski expresses the loss of her man. She has been betrayed by her man or lover and reacts to this with anger saying in the last stanza: "My rock is the mountain. / Love me / if you can. / I will not make it easy for you / anymore." 15

There is no doubt that Wakoski has been betrayed in one way or another. Her father has neglected her, as her friends, husband and lover have done. According to Ostriker, Wakoski dedicates "The Motorcycle Betrayal Poems," to "All men who betrayed me at one time or another, in hopes they will fall of $f$ their motorcycles and break their necks." ${ }^{16}$ So the expression and release of rage and anger are major aspects in Wakoski's poetry, which is an autobiography of her imagination as a consequence of her life experiences. In addition, in her works she explores highly personal experiences such as pain, loneliness and the loss of love as her predominant themes.

It seems that Wakoski does not succeed in love as well as she does in art-poetry. The vocabulary used in her poetry can be an expression of her powerlessness over a situation that she cannot control. She uses language to depict the male as lover, hero and father, but also to demystify, attack and ridicule male figures who have oppressed her life. Thus, her life is the same haunting preoccupation with love which is carried out more in fantasy than in reality. It is the failure of this relationship with men that generates the force for her works.

In order to demonstrate this fantasy, her poem "A Valentine for Ben Franklin Who Drives a Truck in California" is an example. In this poem, she is enchanted by her man whom she calls "magician," and she wants to be the "illusionist" just to create the fantasy in which she can touch him and be touched. She says in line 21: "His hands turned my body into new honey." ${ }^{17}$ However, at the end of the poem

\begin{tabular}{ll}
\hline 14. & Healey, 59. \\
15. & Healey, 61. \\
16. & Ostriker, 141. \\
17. & Ellmann, 1494.
\end{tabular}


she finds herself alone and confused, wondering, "Is he / still driving the freeways of California? or Is he / only an illusion / in my own / magician's head?" ${ }^{18}$ In fact, Wakoski writes about what she cannot obtain in real life, while at the same time looking very deeply into herself.

Her poems are very long monologues confessing her difficult childhood full of fear and loneliness; in fact they might perfectly well be letters she never mailed. Moreover, she addresses the men who loved her or betrayed her; creating from these situations poems of loss such as: the loss of childhood, father, husband and lover. Because she is concerned with beauty, she realizes strongly the self-pity that a woman lives with when she thinks she is not beautiful. In her book entitled, The Man Who Shook Hands, Wakoski refers to her physical appearance by saying, "For realistically what am I? Not a beautiful, slender, tan beach girl Cinderella, but a short, stocky, usually pale, plain woman." 19

Some female poets have taken the writing of male poets as their model, and Diane Wakoski is no exception. As Claire Healey states, "along with Wallace Stevens, whom she admires and to some extent tries to imitate, her aesthetic considerations are manifested in her search for beauty. For her, beauty is revealed as it is filtered through the mind and body." ${ }^{20}$ Now, Wakoski talks about beauty and she gives more importance to the internal beauty of the body-feelings. In her poetry she portrays herself as a victim since she has not been accepted due to her external appearance; on the contrary, she has been rejected because of her looks. She is tired of being alone. Her first betrayer was her own father when he left the family. She says, "the man who rejected me and left me / when I was under two." ${ }^{21}$ However, according to Greiner the betrayer of this continually downtrodden person is she

18. Ellmann, 1494.

19. Diane Wakoski, The Man Who Shook Hands (Garden City, New York: Doubleday, 1978) 14.

20. Healey, 1.

21. Ellmann, 1488. 
herself. Wakoski says, "My face has betrayed me again," adding, "My face shimmering and flat as the moon / with no features." 22

In Greiner's opinion, the great betrayer is her own face; moon faces are not related to beauty, so that her non-acceptance or lack of success with men and love is due to her external appearance which does not appeal to men. To a certain extent Wakoski dislikes men without realizing that it is herself she truly hates. She wants to be desired by men, but inevitably all men betray her and she is left alone and empty. For example, in her book, Virtuoso Literature for Two and Four Hands, in the poem "Cobra Lilies in the Supermarket," she expresses her pain and anger because a man has left once again:

\section{My own mother \\ said, referring to my fourth husband \\ Who left me \\ What are you crying for? \\ buy your own house so that the next one who \\ leaves you won't be able to take your home away. $^{23}$}

Diane Wakoski is among those female poets who know the taste of anger very well. The writing of her poetry functions as did the piano when she was younger-a means of venting her frustrations and anger. This release, which I call "frustrated passion," will definitely clear the way for the future writing of other contemporary female poets. Her poetry is sometimes confusing and difficult to read; however, understanding that her poetry is concerned with the myths and confusions of male-female love, makes certain outstanding issues clearer.

Perhaps her theme of betrayal and the manner in which she expresses her anger toward men reflect the fact that women are more

22. $\quad$ Donald Greiner, ed., American Poets Since World War II, vol. 5, Dictionary of Literary Biography (Detroit: Gale, 1980) 360.

23. Diane Wakoski, Virtuoso Literature for Two and Four Hands (Garden City, New York: Doubleday, 1975) 30. 
intimacy-oriented than men. She expresses hatred toward men for not being faithful and honest with her. In another of her poems, "Love Poem to Leon Edel and Ross MacDonald," Wakoski discloses the real reason why she has not been successful in love:

I know a number of men who interest me, but they are more interested in slim hips than in reality. Why have we all paid so much attention to the physical? It has done nothing to help the cause of the living. ${ }^{24}$

Although Wakoski is a genius in poetry, more attention is paid to external factors than to internal ones. It is pitiful how people are rejected and treated because of their looks and intelligence. Like Wakoski, other intelligent women suffer the same problem of being rejected by men in this patriarchal system. Helene Cixous, a well respected essayist, dramatist and literary critic refers to this situation in her article "Castration or Decapitation": "it is a system of absolute equivalence ... of no inequality, for inequality is always interpreted by the masculine as a difference of strength, and thus as a threat. ${ }^{25} \mathrm{In}$ fact, Wakoski's intention in writing her poetry of anger is to search for reciprocity among the people she loves. In her book, The Man Who Shook Hands, she says, "this is an essay for those of you-David and Annette-who love me, and for those of you whom, reciprocally, I do love and there can be no doubt of that. ${ }^{26}$ Here, she is bitterly leaving out and betraying all those people who in one way or another did some harm to her.

In conclusion, this reaction of anger in Wakoski's poetry addressing some male figures is a problem that not only women, but

24. Wakoski, 1975, 41 .

25. Helene Cixous, "Castration or Decapitation?," Contemporary Literary Criticism, trans. Annette Kuhn, 2nd ed. (New York: Longman, 1989) 485.

26. Wakoski, 1978, 25. 
also men have at one time faced. It is generally assumed that men tend to be more logical and less dreamy than women. In Alicia Ostriker's essay "What are Patterns For? Anger and Polarization in Women's Poetry," she refers to this relationship between Wakoski and her men:

giving Wakoski's sense of the relations between herself and men, she can win all her battles and still lose her war, for the feminine self needs the masculine, but cannot believe it reciprocally needs her. Whether outside or within the self, the male remains Wakoski's antagonist. ${ }^{27}$

Definitely, this essay serves to clarify doubts that her readers may have while reading and studying her poetry. Her anger is a protest to make people search for beauty in the hearts of every human being and not only in physical appearance. Until there is such reciprocity and equality there will always be poets like Diane Wakoski who will portray males as antagonistic figures and therefore, poetry of anger and wrath will always exist.

27. Alicia Ostriker, "What are Patterns For? Anger and Polarization in Women's Poetry," Feminist Studies 10 (Fall 1984) 495. 